\title{
Moisture Damage
}

National Cancer Institute

\section{Source}

National Cancer Institute. Moisture Damage. NCI Thesaurus. Code C62910.

Problem associated with damage inflicted upon the device from water vapor or water in the immediate environment in which the device is being used. 